\title{
Units of Synonymy and Lexical Relations
}

\author{
Dr. Leonard Danglli \\ Department of English Language \\ Faculty of Foreign Languages, University of Tirana \\ E-mail: leonarduniversity@gmail.com
}

\section{Doi:10.5901/ mjss.2014.v5n13p0522}

\begin{abstract}
This papers focuses on a number of lexical relations such as synonymy, antonymy, polysemy and homonymy, with special attention paid to the relationship between synonymy and the other lexical relations. Firstly, the problem of synonymy units is discussed, followed by an analysis of how different lexical relations help study and understand each of them. Moreover, a better understanding of synonymy in such a web of relations, makes language users realize the complexity of synonym use, especially in terms of context. This paper aims to show that a thorough analysis of synonymy requires the analysis of the interrelationship between this lexical relation and the other ones mentioned above.
\end{abstract}

Keywords: synonymy, unit, polysemy, antonymy, homonymy.

Whenever we discuss the linguistic phenomenon of synonymy, a highly controversial question emerges, that of the linguistic units between which the synonymy relation is established. The traditional approach considers words as units of synonymy between the members of a synonymous pair or group. There is even a more "radical" view of synonyms, restricting them to words of the same part of speech. For example, there are a number of definitions by various authors who consider the word as the synonymy unit. Here are some of them:

"synonyms are words of identical or nearly identical meaning" (French, 2004:146)

"near-synonyms are words which share a salient common core of meaning, but differ in relatively minor respects." (Aronoff, 2002:9)

"two or more words with very closely related meanings are called synonyms" (Yule, 2006:104)

Such definitions seem to stem from the definition provided by the "inventor" of synonymy, Aristotle in his "Rhetoric" (synonumon "with the same name; syn-with, onuma -name). As a result, dictionaries of synonyms prepared over the years have used the word as the basis of the synonymy relation. Nevertheless, this sounds justifiable and reasonable given the practical function of the matter. Moreover, dictionaries generally reflect the existing theoretical basis and take it to a practical level for general use. Thus, as the greatest number of studies have focused on the word as the unit of synonymy, it is then expected from dictionary compilers, who may have sometimes been authors of the studies on synonymy themselves, to use the word as the basic unit of a dictionary of synonyms.

However, it must be pointed out that there has been a growing tendency to extend the scope of synonymy relations both below and above the word. For example, such a tendency is evident in two monolingual dictionaries in both English and Albanian, where units other than the word have also been included in the definition of synonyms:

"synonym - a word or expression that has the same or nearly the same meaning as another in the same language" (OALD, 2000:1319)

"synonym- a word, expression or construction with identical or very similar meaning with the meaning of another word, expression or construction" (AKSH, 2002:1182)

Roy Harris (1973), who has written a book on synonymy, has made it clear in the introduction of his book "Synonymy and Linguistic Analysis" that the traditional definition of synonyms has been replaced by a wider and more inclusive notion of synonymy, including units below and above the word. According to him, synonymous expressions (this 
is the term he frequently employs to refer to synonyms) include words, morphemes, phrases, clauses, sentences and sequences of sentences.

Other scholars have modified the traditional conception of synonymy by including units below the level of the word, such as morphemes. For example, the ending -en in oxen is viewed by some as a synonym of the standard ending $-s$ in the word cows (Lonngren). However, confusion emerges in terms of terminology as some prefer the term "grammatical doublets" or "grammatical parallels" instead of synonyms. Others have gone even further and have identified examples of synonymy beyond semantic units. It is the case of syntactic units. For example, a synonymy relation is observed in the sentence below:

She knows (that) you are...

It is argued that in this case synonymy is established between the sentence with a conjunction and the case without the conjunction.

Mansaku (1985), by bringing an example of syntactic synonymy, helps the discussion about synonymy beyond the word. The three sentences below are considered synonymous by him:
a) Gjuha e shkrimtarëve të mëdhenj është e thjeshtë dhe e pasur.
b) Gjuha e shkrimtarëve të mëdhenj karakterizohet nga thjeshtësia dhe pasuria.
c) Karakteristika të gjuhës së shkrimtarëve të mëdhenj janë thjeshtësia dhe pasuria.

If we stick to the belief that synonymy holds solely between words, is it then possible to deny the existence of synonymy between words and other constructions, such as pregnant - in the family way, vdiq - na la shëndenë, etc. As a result, a more comprehensive view of synonymy would encompass not only words as units of synonymy, but even more complex linguistic constructions.

Nevertheless, synonymy is better analyzed when viewed in connection with other lexical relations such as antonymy, polysemy or homonymy. For example, knowledge of the polysemantic structure of words is essential for analyzing synonymy relations. Polysemous words can establish relations of synonymy in one or several of their senses but not all of them.

Antonymy and synonymy are also highly important when it comes to discussing synonymy. According to Samara (1985) a number of types of relations between synonymous chains are established on the basis of opposite meanings of polysemous words and their proximity with other Albanian words. The size of these chains varies from language to language. Here is such an example from Albanian: $i$ martuar (married) - $i$ pamartuar (unmarried), beqar (single).

Synonymy can also be identified in what is known as "stylistic antonymy", which is a special type of antonymy in Albanian. Samara (1985) has provided the following classification of stylistic antonyms:

a) stylistic antonyms (mësues - dhaskal) formed by the opposition between the stylistically neutral word and its obsolete synonym which has gained emotional associations. English language is also rich in pairs of stylistic antonyms (enemy - foe).

b) stylistic antonyms (litar - fortomë or helmohet - farmakoset) formed by the opposition between the general word of common use and the respective regional or foreign word, with restricted contexts of use and stylistically marked. Here is a pair of such stylistic antonyms in English: brotherly - fraternal.

c) functional stylistic antonyms (gazetë - lëpushkë, atdhe - mëmëdhe, bëj - kryej, e vrau - e palosi), formed by the opposition between synonyms pertaining to different levels of discourse or different functional styles of the language. The pair die - pass away constitutes an example of functional stylistic antonyms in English.

d) stylistic antonyms formed by the opposition between two meanings of the semantic pattern of the same word: the positive or neutral meaning and the pejorative meaning which is generally put in inverted commas or accompanied by such determiners as "gjoja", "i ashtuquajtur". Here is an example of such a type of stylistic antonymy: trim (real) - "trim" (not real).

The classification made above once again emphasizes the overall complexity of lexical relations, with the same pair or set of words being included in two different lexical relations. Nevertheless, such an interconnection gives a better insight into the essence of the lexical relations discussed so far because discussing them in isolation does not help us carry out a thorough and comprehensive treatment of such linguistic phenomena.

Moreover, compound antonyms can enter into a relation of synonymy with each other. For example, the Albanian compound word fjalëpakë can enter into a relation of synonymy with fjalëkursyer, while fjalëshumë can enter into a relation of synonymy with fjalëmadh or fjalëgjatë; shpirtmirë is synonymous with shpirtbutë, zemërmirë and zemërbutë; on 
the other hand, the antonym shpirtkeq is synonymous with shpirtlig, shpirtegër and shpirtashpër, zemërkeq, zemërlig. The Dictionary of Albanian Language (2002) contains a great number of compound synonymous words with the first member zemër or shpirt, which can establish a relation of antonymy with a longer chain of respective words of opposite meaning.

Antonyms and synonyms are frequently grouped together when it comes to "semantic relations between words of no common origin both in terms of formation and meaning, i.e. between different words of no common derivation, but they share a common semantic axis" (Thomai, 2005:129). These kinds of relations are known as semantic unconditional relations, thus contrasting with semantic conditional relations such as derived and non-derived words.

The interrelation between synonymy and antonymy has also been analyzed by Cruse (1986), who states that the difference between synonyms and antonyms is that in synonyms their common traits are more important than the differences between them.

Palmer (1981:92) admits the importance of antonyms in the discrimination of synonyms. Just like the substitution test, he considers antonymy a means for testing synonymy. Thus, superficial is opposed both to deep and profound, whereas shallow is opposed only to deep. The fact that two words seem to have the same antonyms may be a reason for considering them synonyms, but the examples given above show that there are words interchangeable in certain contexts and it is in the context that deep and profound are interchangeable that their common antonym is superficial.

Synonymy can be of help when it comes to distinguishing homonyms from polysemy. One of the ways to make this differentiation is as follows: there are homonyms when two words can correspond to different synonyms. For example, çojı "dërgoj" / çojı "ngre lart"; bieı "rrëzohem" / bie/I "sjell"/ bieIII "godit" etc. There is polysemy when two senses correspond to a common synonym: gjëmon (moti) and gjëmon (lufta) "buçet, kërcet, uturin" etc. (Thomai, 2009:153)

The development of polysemy can be regarded as an abundant source of synonymy relations. With the passing of time words of different etymology meet in some of their senses. Let us focus on the English words courage and bravery. Despite their etymological difference, these two words now share one of their senses.

Bravery

- The quality of being brave; courage; valor.

- Fine appearance, show, or dress; showiness.

- Etymology - French, braverie, glantry, splendor

\section{Courage}

- The attitude of facing and dealing with anything recognized as dangerous, difficult or painful, instead of withdrawing from it; Quality of being fearless or brave; valor.

- Mind; purpose; spirit.

- Etymology - ME \& OFr, corage, heart, spirit (Gove, 1984)

On the other hand, a great number of Albanian words are synonymous with each other in or more senses of their semantic structure. For example, the verb çoj is synonymous with the verb ngre in the sense "lëviz diçka nga poshtë lart" (çoj dorën - ngre dorën), whereas in the sense "ia nis dikujt diçka" the verb çoj is synonymous with the verb dërgoj ( $i$ çoi një letër, i çoi fjalë dikujt - $i$ dërgoi letër, i dërgoi fjalë dikujt). As a result, the very same word may have different synonyms in different senses.

Synonymy relations between word senses are also observed between words deriving from different dialects of Albanian. For example, the verb këndoj in the Southern dialect is synonymous in one of its senses with the verb lexoj.

As the majority of words in a language are polysemous, the same word may belong to various synonym sets. This is the case with the word fresh:

A fresh metaphor - fresh; original; novel; striking.

To begin a fresh paragraph - fresh; another; different; new.

Fresh air - fresh; pure; invigorating.

A freshman - fresh; inexperienced; green; raw.

To be fresh with somebody - fresh; impertinent; rude.

Rodman (1993) has also paid attention to this linguistic phenomenon. According to him, a word may consist of a number of senses which are similar and at the same time slightly different. This polysemous word may share one of its senses with another word, resulting in a kind of partial synonymy. For example, mature and ripe as polysemous words 
are synonymous when referring to fruits but not when referring to animals. He also takes the example of deep and profound (mentioned above) as a pair of synonyms, with both members used with reference to thoughts, but only deep is used when referring to water.

It must be also highlighted that "the size of the synonym set of a word is usually in direct proportion to the size of its semantic pattern. Words of a broad semantic pattern create the largest groups of synonyms in Albanian. For example, the verb zë, with 30 senses, creates a group of over 120 synonyms; the verb bëj has approximately 90 synonyms." (Thomai, 2005:7)

To conclude, synonymy must be analyzed both in terms of inner and outer relationships. Being a lexical relation, synonymy cannot avoid interrelating with other lexical relations such as antonymy, polysemy or even homonymy. Studying them in terms of interconnection and interdependence may help language users better manage the use of the appropriate word in a given context.

\section{References}

Aronoff, M., Rees-Miller, J. (2002). The Handbook of Linguistics, Blackwell Publishing.

French, A. P., Wettstein, K. H. (2004). The American Philosophers, Wiley- Blackwell.

Harris, Roy (1973). Synonymy and Linguistic Analysis, Blackwell.

Mansaku, S. (1985). Rreth sinonimisë sintaksore në shqipen e sotme letrare, Gjuha jonë, Akademia e Shkencave.

Merriam Webster's Dictionary of Synonyms, Merriam Webster, 1984.

Oxford Advanced Learner's Dictionary (2000), Oxford University Press.

Palmer, F. R. (1981). Semantics. Cambridge: Cambridge University Press.

Rodman, R. (1993). An Introduction to Language, Harcourt Brace Jovanovich Publishers.

Samara, M. (1985). Çështje të antonimisë në gjuhën shqipe.

Thomai, J. (2005). Fjalor Sinonimik i Gjuhës Shqipe, Tiranë, Dudaj.

Thomai, J. (2005). Leksikologjia e gjuhës shqipe, Tiranë, Dudaj.

Thomai, J. (2009). Prejardhja kuptimore në gjuhën shqipe (Semantikë leksikore), Tiranë, EDFA.

Yule, G. (2006). The Study of Language, Cambridge University Press. 